\title{
Organisation of Self-Government in the Republic of Macedonia
}

\author{
$\mathrm{PhD}$ (c) Ramiz FAZLIU
}

\begin{abstract}
The subject of this paper is the constitutional and legal regulation of local self-government system in the Republic of Macedonia, territorial division, the process of reforming and building this system since the independence of the Republic of Macedonia from the former federation of Yugoslavia. With the intention of functioning and materialization according to democratic principles, since the independence of Macedonia the system of local self-government has undergone through continuous reform process. These reforms first of all are mostly related to the territorial division of local self-government units, seeking the most appropriate model which would be appropriate to the general developments of Macedonia. In this paper is analyzed the role and the constitutional and legal position of local selfgovernment units, in this case the municipality, as the only unit of local self-government, its legal status, competences, representative and executive bodies, financing and the process of decentralization. It is also analyzed the model of organization of local self-government in the city of Skopje, as a capital of the Republic, in the form of community of municipalities in the city and the impact of the Ohrid Agreement on the regulation and functioning of local selfgovernment in Macedonia.
\end{abstract}

Keywords: Local Self-government, Macedonia, Municipality, agreements

\section{Introduction}

Republic of Macedonia, as unit of the former Yugoslav federation, is the only republic (which was not the case with other republics as federal unit) which gained its independence peacefully, during the breakup of the former Yugoslav federation, through a referendum in 1991.

Macedonia is a multiethnic state, even though by the constitution is not defined as such. Based on the data of the State Statistics Office, Republic of Macedonia has an area of $25.713 \mathrm{~km} 2$, according to the 2002 census, 2,022,547 people living in Macedonia. According to the census the ethnic structure is as follows *: $64,2 \%$ Macedonians, $25.2 \%$ Albanians, $3.8 \%$ Turks, Roma 2. 7\%, 1. 8\% Serbs, Vlachos $0,5 \%$ and $1,8 \%$ not defined ${ }^{1}$.

The issue of the organization and territorial division of local government units in the Republic of Macedonia is addressed since 1952, namely in 1962, when the territory of this republic is divided into administrative-territorial units - municipalities. This administrative division but also the local government had 34 municipalities, a system that was applied until 1991, and today in the country operate 84 municipalities and the city of Skopje as the capital of the republic is organized by a special law on local self-government, as a community the municipalities of the city of Skopje.

\section{Constitutional and legal regulation}

With the adoption of the constitution of the independent state of Macedonia in 1991, the system of local self-government sanctioned by the specific provisions and it is considered one of the fundamental values of the constitutional order ${ }^{2}$. By this

\footnotetext{
* Note: This is the last population census (2002). Because the regular census of 2012, was halted without being completed for political reasons and 'national security', as was the excuse of state authorities. But probably the main reason as were warnings that the Macedonian population is decreased and predictions were that the Macedonians will have less than $50 \%$ of the entire population of the Republic of Macedonia

Republic of Macedonia State Statistics Office, Skopje, www.stat.gov.com

2 The Constitution of Macedonia, Article 8
} 
Constitution, to all citizens of the Republic of Macedonia is guaranteed the right for local government ${ }^{1}$. By the Constitution, only the municipality is provided as a unit of local self-government.

The territorial division is done by a special law, and the citizens participate directly or through their representatives, in decision for issues of local importance, especially in the areas of public services, urban and rural planning, environmental protection, local economic development, local finance, culture, sports, social and child protection, education, health and other areas prescribed by law2. Therefore the municipality is the only unit of local self-government, and the local selfgovernment system in Macedonia is in the same level and same competences for all municipalities, regardless of territory, number of inhabitants or the level of economic development except Skopje.

City of Skopje as a separate unit of local self-government and the capital of the Republic has also organized local government by a special law33.

Apart from the constitutional provisions the local government system in Macedonia is regulated also by special laws: the Law on Local Self-Government of 1996 and 2002. 2004. Law on territorial organization of the municipalities in the Republic of Macedonia ${ }^{4}$. The territory of Macedonia is divided into 84 municipalities, while Skopje has special status as the capital and with a particular form of organization - the Community of Municipalities of the city

\section{Organizational structure and competences of local self-government units - municipality}

Municipalities as local self-government units are legal entities organized under the Law on territorial organization of local self-government and the Law on the City of Skopje. Currently according to these laws the Republic of Macedonia has 84 municipalities. The territorial division of municipalities is leaded by the principle of separation map and municipal boundaries do not follow ethnic lines but above all territorial division based on principles and relevant criteria to the whole territory of Macedonia.

The law requires that: the territory in which the municipality is established with its boundaries, coinciding with the cadastral boundaries of municipalities, which must present a set of natural geographic and economic connection with road infrastructure between settlements and gravitation towards the common centre, and have the infrastructure facilities and social standard facilities built 5 .

Based on these principles by 84 municipalities, there are significant differences between them as to the territorial space, economic development and population.

Therefore ps. Municipality Vraneshtica counted as municipality with fewer inhabitants which has only 1322, or that Kumanovo as municipality with more inhabitants with $105,484^{6}$, while the area the largest municipality is Prilep with 1194 $\mathrm{km} 2$, the smallest is Çair municipality, with the area of $3.5 \mathrm{~km} 2^{7}$ only.

The Law on Local Self Government in 2002, municipalities have two types of competences:

- own competencies and

- delegated competences

By Article 22 of this law is defined the list of competencies for which municipalities are charged to perform work in the public interest and they are: Urban Planning (urban and rural), protection of environment and nature, local economic development,

\footnotetext{
1 The Constitution of Macedonia, Article 114

2 Same, article 115

3 The Law on local self-government in the city of Skopje, 1996

4 "Law on territorial organization of the municipalities in the Republic of Macedonia ", 2002

5 Law on Local Self-Government, Article 17 and 18, OG No.28 / 2004

${ }^{6}$ Report, the Institute for Policy Studies intercultural Macedonia, May 2009

7 Wikipedia, Municipalities of Republic of Macedonia ( www. Wikipedija / 3.3.2016). 
communal activities culture, sports and recreation, social protection and child protection, education - establishment, financing and management of schools up to the secondary level in cooperation with the central government, primary health protection, measures for protection and rescue of citizens, protection against fire, supervision over carrying out performance of its competences and other tasks stipulated by law ${ }^{1}$.

Delegated competences to the municipalities defined by Article 23 of this Law as follows:

1. The state administration bodies may delegate the performance of certain issues of its competences to the mayor, in accordance with the law.

2. In the cases of paragraph (1) of this Article, shall be funds from the budget of the

Republic of Macedonia to carry out those tasks.

3. The method of performing the tasks referred to in paragraph (1) of this Article may be

adjusted to local conditions, respecting the standards set by law.

The State Administration of paragraph (1) of this article in subsidiary order is

responsible for carrying out the delegated tasks².

\section{Bodies of Local Self-Government Units}

The Law on Local Self Government and Municipal bodies are: the Council and the Mayor ${ }^{3}$.

- The Council as representative body of the citizens of the municipality and the City of Skopje, as a collegial body issued the charter, rules and regulations of the local level or the municipal scope prescribed by law. The law explicitly states and has defined the competences of the council of the municipality / city of Skopje as follows: issuance of municipal statute I Skopje, issuance of decisions and other acts. Extraction of spatial and basic and detailed urban plan, budget and final accounts for implementation of the budget. Municipality / City of Skopje has the right to organize a referendum, establish municipal bodies, organizations, services and funds, elect and dismiss the President and Vice President of the Council, selects, appoints and dismisses holders of other public municipality conducts surveillance the work of municipal bodies, organizations, services and funds, cancels and abolishes acts of organs of municipal council, ensures the implementation of laws and other provisions for which is authorized by the Government, issue regulations for its tasks and perform other tasks defined by the constitution, law and statute of the municipality 4 .

The statute of the municipality / city of Skopje determines organizing body of the municipal council. City councillors and the number of which is determined depending on the number of inhabitants in the municipality and can not be less than nine (9) municipalities up to 5,000 inhabitants and no more than 33 , the municipalities over 100,000 inhabitants ${ }^{5}$. The municipal council consists of elected representatives in local elections, direct and free elections by secret ballot and plurality, the Council from among its members elect the President of the council of the municipality / city of Skopje. He leads and manages the sessions of the council, cares for the progress of work of the Council and performs prescribed by law and municipal statute. The president of the Council for its work is responsible to the Council of the municipality / city.

\footnotetext{
${ }^{1}$ Law on Local Self-Government. 2002

2 Same, article 23

3 Law on Local Self-Government, article 31

${ }^{4}$ Same, article 36

5 Same, article 34
} 
The Mayor is the executive organ of the Municipality / City of Skopje, which is elected by general, direct, and free elections by secret ballot in accordance with the law regulating local elections ${ }^{1}$. The Mayor by law and municipal statute is the highest executive body of the municipality, a Mayor who represents the citizens and represents the municipality and state authorities. Mayor performs and duties that are prescribed by law and held responsible for the tasks delegated by the central municipality. He manages the municipal administration, propose and issue decisions, regulations and other regulations dealing with the municipal administration, proposes and implements municipal budget, appoint management staff of the municipal administration and enterprises, institutions and public funds communal care for municipal public property and overseeing the legality of the acts before the announcement.

The Mayor of the Municipality / City of Skopje issues decisions in administrative proceedings at first instance. With these acts he decides to exercise the rights, obligations or legal interests of citizens in the concrete municipality of its territory defined by law and fall under the jurisdiction of local self-government unit. Against acts decisions of the Mayor, the unsatisfied parties may challenge (complaint) through the relevant Ministry of the central level, in cases where no appeal is permitted by law, the decisions of the mayor are final and aggrieved parties in such cases may raise only an administrative lawsuit at the administrative Court. The mayor's mandate is four years (4) and complies with the mandate of the municipal council as regular elections prescribed by law.

\section{City of Skopje - a special unit of local self-government}

The City of Skopje is a special unit of local self-government, in which are implemented the common needs and interests of citizens arising from the status of the city of Skopje, the capital of the Republic of Macedonia ${ }^{2}$. Taking into account the special position of the city of Skopje, the municipality and the local government unit, organization, competences and functions do not differ substantially from other municipalities in the country. Therefore, the Law on Local Self-Government of the Republic of Macedonia decisively emphasizes that the provisions of the same law apply in full for the city of Skopje, as well as the Law on Local Self-Government of the City of Skopje, except those provisions which by this law are foreseen otherwise ${ }^{3}$.

The Law of the City of Skopje regulates the competences of the City of Skopje, organizing the tasks of its organs, the direct participation of citizens in decision-making, ways of financing, the protection of local self-government, IMC municipalities within the city, including the municipalities in the City of Skopje, etc..

City of Skopje as Macedonia's capital as a whole and single territorial, urban, economic, political and ecological, includes the following municipalities: Center, Kisela Voda, Gazi Baba, Çair, Karpos, Shuto Orizari and Djordje Petrov.

\section{Financing the local self-government units}

Local self-government bodies to implement and fulfil the duties and obligations imposed by the law must have the necessary financial exploitation. The local government has the right to adequate financial resources. The issue of local government financing, is one of the core issues that should be paid special attention to the fact that without funding there is no proper functioning of local self-government bodies, namely the provision of services with modern standards. How important is this issue more clearly speaks the principle arising from the European Charter on local self-government, where this principle is ranked one of the key principles for the organization and functioning of local government units and obliges governments of the countries to foresee that matter by specific constitutional and legal provisions.

Local self-government units in Macedonia have two types of funding and resources, income source (own) and additional funds in the form of grants from the budget of the Republic.

The first group includes the income of resource defined by law: taxes (a part of the income tax, the tax asset left in inheritance and gifts of real estate) taxes on municipal land, municipal fees and income from services; income from its own

\footnotetext{
1 Same, article 49

2 Law on local self government in Republic of Macedonia, Skopje 1995, Article 4. provision 1

${ }^{3}$ Law on local self government in Republic of Macedonia, Skopje 1996, article 16

${ }^{4}$ Same, article 4 provision 1 
assets, tax revenues Republican or outside (in-kind or cash), profits from enterprises and public services established by the unit of local self-government revenue from fines for breaking the rules of the unit of local self-government; other revenues as provided by law.

The second group of income includes additional funds from the budget of the Republic and income in the form of a loan from the budget of the Republic, not to stop the functioning of local self-government units ${ }^{1}$.

In addition to these sources of funding for this period the local government units in Macedonia are financially supported by many international governmental and nongovernmental organizations to realize more public infrastructure projects. But it should be noted that the allocation of the state budget, the local self-government units with Albanian majority are continuously discriminated by the Government of Macedonia, and this is best evidenced that Albanian municipalities are and remain among the most underdeveloped municipalities in the Republic of Macedonia, where the Albanian political factor is also responsible.

\section{Ohrid Framework Agreement and local self-government}

The organization and functioning of local self-government in Macedonia has support directly by the basic principles of the Ohrid Framework Agreement, namely the third and fifth principle stating: it is decided based on these basic principles:

Third Principle - There are no territorial solutions for ethnic issues;

Fifth Principle - Development of local government is essential for encouraging the participation of citizens in democratic life and for promoting respect for the identity of communities².

With this agreement, which is in full compliance with the European Charter of Local Self-Government, municipalities, in particular those with an Albanian majority is recognized the authority for governance as in the sphere of public services, urban planning, rural development, culture, education, social protection and health, local finance, etc..

Although the laws mentioned are approved, but implementation in practice is far from what the Macedonian government authorities committed.

With this agreement the Macedonian authorities took the obligation to make the necessary constitutional and legal changes related to: the decentralization of power (empowerment of local government units), fair representation of Albanians and non-discriminatory in all levels of administration and state institutions, changing procedures councillors practicing qualifying principle of majority $(2 / 3)$ to amend the constitution and some systematic laws that affect the rights of communities that are not majority in Macedonia, the right for education and the use of language as an official language spoken by at least $20 \%$ different from the Macedonian language, expression of national identity through ethnic community symbols, etc.

Although the framework agreement envisaged to become a reality at the latest by the end of 2004, this term not only was not respected but there were delays and not proper deviations. For, not fulfilling the obligations arising from the agreement can not be blamed only the government of Macedonia, but the best part of the responsibility belongs to the Albanian political factor for pursuing a policy incoherent and fragmented throughout this time.

Critical points on this agreement were not realized based on the dynamics of which we consider vital for the Albanian population are:

First, not official use of the Albanian language as second official language in Macedonia, even though, by the Constitution this right is defined exactly: Any other language spoken by at least $20 \%$ of the population, is also official language. So, the rate of $20 \%$ is provided that a language gets the status of official use. However, this constitutional provision is modified "neatly" in the Law on Use of Languages (2006). Article 2 of the Law states: "The state organs of the Republic of Macedonia 
can use the official language other than Macedonian1. Here we have a substantial change of the constitutional determination that the use of the official language is expressed with "is" and the by law "may". So, the Albanian language is not used by default, but can be used or not, this is a substantial change.

Second, by the Ohrid agreement the fair representation has following wording: "we will fully respect the principle of nondiscrimination and equal treatment of all persons by the law". This report shall apply to employment in the administration and public enterprises. But even to this day there is still not adequate representation of Albanians in state institutions and in the Macedonian central and local level of government.

Third, the decentralization in all fields especially in the field of finance was replaced by classic de concentration.

Delays that brought not timely implementation of this agreement were enough to frustrate citizens, and primarily the Albanians, who are reflecting the idea of alternative competitive "market" of political ideas for new internal adjustment of the political system in Macedonia. So there are many reasons to demand accountability from those who have delayed the implementation process of the agreement, whether in the current government, or precursor. The common denominator of all delays in this process has been playing obstruction deadlines, insincere game between coalition partners.

\section{Conclusion}

The organization and functioning of local self-government, namely the organization of territorial units in Macedonia since its independence has been continuously subject to the reforms and changes, not only in number but also in their core competencies. Initially, immediately after the adoption of the first laws in this area, from 34 municipalities were established 124 municipalities which operated until 2004, and with legal changes that number was reduced to 84 which currently operate.

Republic of Macedonia, although is a signatory to the European Charter of Local Self-Government, even today does not comply with the basic principles of the Convention, related to decentralization and local autonomy in general and in particular financial autonomy is because the competences of local government (municipal) are almost completely squeezed under the jurisdiction of the central government or respective ministries, such as education, culture, health, social issues, etc. while the justice and interior were completely centralized. So, the concept of regulation and the division of competences between central and local government in Macedonia, there was no question of decentralization of competences but for the classic de-concentration of responsibilities for carrying out tasks with local character, in this case the municipality as a unit of local self-government.

\section{LITERATURE}

1. The Constitution of the Republic of Macedonia, Skopje, 2006

2. Law on Local Self-Government of the Republic of Macedonia, 1992, 1995. 2002

3. The law on local self-government of the City of Skopje, Skopje, 1996. 2004

4. Law on the organization and work of state bodies, Skopje 2000

5. Law on Territorial Organization, Skopje 2004

6. Law on the territory of municipalities, Skopje, 1991

7. Law on Use of Languages, Skopje, 2008

1 "Law on use of languages...", Skopje 2008 
8. Agni Aliu \& Esat Stavileci: Local Governance, Tetovo-Prishtina, 2009

9. European Charter of Local Self-Government, Strasbourg 1985

10. Report, Policy Institute for Intercultural Studies in Macedonia, Skopje, 2009

11. State Statistical Office, Republic of Macedonia, Skopje, (www. stat. gov. com)

12 Ohrid Framework Agreement, August 13, 2001

13. Wikipedia, Municipalities of Republic of Macedonia (www. wikipedia. com, 03/03/2016) 